УДК 821.161.1Вод7]Брі.08

UDC 821.161.1Вод7]Брі.08

DOI: $10.31475 /$ ped.dys.2021.30.11

КАТЕРИНА КАЛИНИЧ, аспірантка

(Украӥна, Чернівиі, Чернівецький національний університет ілені Юрія Федьковича, вул. Коцюбинського, 2)

KATERYNA KALYNYCH,

Postgraduate student (Ukraine, Chernivtsi, Yuri Fedkovich Chernivtsi National University,

Kotsiubynskyi St., 2)

ORCID: 0000-0002-8263-6322

\title{
Художній текст як ілюстративне джерело значення парадигми «успіх» у педагогіці:
} роман С. Водолазкіна «Брісбен»

\section{Literary Text as an Illustrative Source of Meaning of Paradigms of «Success» in Pedagogy: E. Vodolazkin's Novel «Brisbane»}

\begin{abstract}
Виокреллено матрицю найнеобхідніших якостей педагога, які безпосередньо впливають на форлування майбутнього їхніх вихованиів. На прикладі персоносфбери ролану Є. Водолазкіна "Брісбен", розглянуто фбактори створення іліджу викладача, які (не)ведуть до педагогічного успіху (вчитель-тиран Леся Кирилівна, педагог-романтик Віра Михайлівна, улюблена вчителька сольбьежжіо Клавдія Василівна, викладач-панібрат Олена Марківна, неприлітний Павло Сєргєєв, моралістка директорка школи, донощиия вчителька суспільствознавства, психологічно стійка Катя, нонконфборліст Іван Сергієнко, досвідчений проббесор Бесєдін, родичка Ліза). На прикладі доцента Чукіна та його взаєловідносин з колегали-ббілологали, розглянуто особливості етичних взаєлин у науковому середовищі. Висвітлено вплив політичної доктрини (радянського союзу) на фбормування особистості вчителя та його викладацьку практику. Простежено визрівання індивідуальності та педагогічної майстерності протагоніста твору Гліба Яновського. Зокрема, підкреслено вплив досвіду стосунків з педагогами на викладащьку практику головного героя. Констатовано відмінність специфбіки вузівського та шкільного викладання. Опираючись на соціологічні опитування та роман "Брісбен", виділено найнеобхідніші профьесійні, індивідуальні особливості та риси зовнішнього вигляду викладача для реалізації успішної взаємодії з учняли та парадигми "успіх" у пробессійнолу ключі. Особливу увагу зосереджено на педагогічних якостя,х актуальних для нашого часу.
\end{abstract}

Ключові слова: Є. Водолазкін, "Брісбен», Гліб Яновський, імідж, педагог, вчитель, викладач, школа, університет.

Success is an important factor in the increase of teacher competence, its implementation as a person, as the professional approach to teaching provides not only the appropriate level of knowledge, but also affects the formation of individual qualities of students. Therefore, the image created by the teacher plays a fundamental role in teaching students, thus, this article shows the implementation of the paradigm of "success" through the prism of pedagogical image. Russian scientist and writer of Ukrainian origin Yevgeny Vodolazkin (1964), based on his own experience of studying in Soviet schools and universities, in the novel "Brisbane" emphasizes the most important qualities that a successful teacher must have. The factors create the image of a teacher who (does not) lead to educational success (a teacher-despot LesiaKirillouna, a teacher-romantic Vira Mykhailivna, favorite teacher of solfeggio Claudia Vasylivna, a teacher and a close friend Olena Markivna, inconspicuous Pavlo Sergeev, a moralist-director of the school, a gossip teacher of social sciences, psychologically stable Katya, nonconformist Ivan Sergienko, experienced professor Besedin, a relative of Lisa). Instead, the peculiarity of the observance of ethical relations in the scientific community among fellow philologists can be traced through the character of Associate Professor Chukin. Through the prism of the image of the protagonist of the work - Glib Yanovsky -, the way of the formation of his pedagogical skill and professional perfection is considered. In particular, the significant influence of the experience of relationships with teachers on the teaching practice of the protagonist has been established. The difference between university and school teaching has a particular importance. It is proved that political ideology (in particular, of the Soviet Union) directly influences teaching practice. Based on opinion polls and the novel "Brisbane", it is highlighted the most necessary professional, individual features and appearance of the teacher to implement successful interaction with students and the paradigm of "success" in a professional manner, 
emphasizing the importance of pedagogical qualities needed by modern teachers .

Key words: E. Vodolazkin, "Brisbane», Glib Yanovsky, an image, a teacher, an educator, a lecturer, a school, a university.

Вступ/Introduction. Найважливішим фактором формування людської особистості є навколишне середовище. У контексті освітянства вагома роль відводиться сім'ї (батьки, родичі), школі, університету, роботі (вчителі, викладачі, друзі, знайомі, колеги). Проте чи не менший вплив на становлення самостійного «Я» відіграе держава та іï політичні маркери, що своєчасно відбивається у мистецтві, зокрема й у літературі.

В означеному аспекті Свгеній Водолазкін (російський письменник українського походження, 1964 р.н.) у романі «Брісбен» (2018 р.) дае змогу простежити еволюцію становлення особистості педагога за часів радянського періоду, починаючи з учнівства та закінчуючи роботою вчителем в школі.

Мета та завдання / Aim and Tasks. Показати реалізацію парадигми «успіх» крізь призму педагогічного іміджу на прикладі роману Є. Водолазкіна «Брісбен».

Методи / Methods. Для здійснення поставленої мети наукової роботи, опираючись на аналіз науково-методичної літератури, було використано такі методи: компаративістичний, рецептивний, аналіз, синтез, узагальнення. Як метод дослідження використано соціологічне опитування, проведене С. М. Захаровою, А. А. Пучковим, Л. П. Іноземцевою, О. І. Поповою.

Результати/Results. Хоча сам автор і заперечуе автобіографічність даного роману («Брисбен» Водолазкин Евгений Германович - описание книги), протагоніст - Гліб Яновський музикант-віртуоз, дублюе чимало фактів із життя Свгенія Германовича: народження в Киеві та пов'язані з ним дитячі спогади, навчання в школі з поглибленим вивченням української мови, закінчення музичної школи по класу домри, пізніше - гітари, вступ на філологічний факультет (російське відділення), переїзд до Петербурга, одруження, перебування в Німеччині (Е. Водолазкин; Интервью: Евгений Водолазкин: «Человек - как печка: долго топится, потом греет других», 2019; Биография. Евгений Водолазкин). Отже, текст, породжений власним життевим досвідом письменника, постае виразним документом.

Дитинство та шкільні роки, описані в «Брісбені», припадають на 70-ті pp. XX ст. - час радянської доби. Євгеній Водолазкін, будучи вихованцем школи тих часів, в одному з інтерв’ю акцентував: «Радянська епоха, на яку припала моя юність, була часом, по суті, аісторичним: нічого не відбувалось. Підручник історії КПСС, зомбаки та мавзолеї - це все здавалось атрибутами вічності. Туга за змінами була настільки великою, що породила ілюзію можливості вирішення всіх проблем силою соціальних змін. Все виглядало дуже просто: змініть соціальний лад - i прийде нове і остаточне щастя» (Интервью: Лицом к лицу. Евгений Водолазкин : «Каждый роман - это вновь создаваемый мир», 2019). У такий спосіб, духовний розвиток, досвід, знання та вміння письменника, як і Гліба Яновського, пройшли через радянський вишкіл з усіма його позитивними та негативними аспектами, сформувавши індивідуальний творчий шлях і автора, і його героя.

За бажанням Глібового батька-українця - Федора - школа, у якій навчався протагоніст, була українською. Справедливо зазначити, що, хоча російська мова, починаючи з кінця 30-х років XX ст., стае обов'язковою i, відповідно, збільшуються години на ії вивчення, проте республіки, зокрема й Українська РСР, бачили своїм завданням забезпечувати навчання дітей рідною для них мовою (С. М. Шевченко, 2013). Однак, як пише Водолазкін, російські школи користувалися більшою популярністю, ніж школи національних меншин:

«У той час, як російські школи ломилися від бажаючих в них вчитися (5 паралельних класів по 45 осіб в кожному), в українських панували спокій і камерність. Клас Гліба налічував 24 учня, а паралельних класів не було. У цій школі навчалися діти українських письменників та - оскільки вона перебувала поруч з вокзалом - хлопці з найближчих до Киева сіл. Гліб не належав ні до тих, ні до інших, i його українська обмежувалася окремими словами, почутими від батька» (Е. Г. Водолазкин, 2019, с. 27).

У романі Гліб жодного разу так і не заговорив українською, однак реципієнт розуміе, що праця вчителів не залишилась осторонь, бо розумів він мову чудово.

Так, на початку твору з'являеться Леся Кирилівна - лиха вчителька російської мови. Недарма автор змальовуе її у стані гніву, підкреслюючи авторитарний стиль її викладання через міміку:

«... в хвилину гніву Леся Кирилівна ворушила губами, щось беззвучно вимовляючи. Тобто дещо в таких випадках вона вимовляла і вголос, але озвучене мало в цілому характер благополучний - принаймні, в порівнянні з виразом їі обличчя. Загадкою залишалося те, що було позбавлене звуку, і вираз обличчя відповідав, очевидно, йому» (Е. Г. Водолазкин, 2019, с. 28).

Вчительці вочевидь бракувало вміння позитивно і правильно налаштовувати учнів на роботу, створювати сприятливу атмосферу, підтримувати креативність дитячої уяви - що гарантувало би 
неабияку успішність уроку, проте, на думку Гліба, «з усіх безрадісних речей не було в ці роки нічого більш безрадісного, ніж уроки російської мови» (Е. Г. Водолазкин, 2019, с. 28). Авторська іронія відмічае належний методичний підхід вчительки до свого предмету, яка вміе зіпсувати навіть цікаве:

«... урок Леся Кирилівна починала з розминки, яка, за рекомендацією методички, включала в себе скоромовки. По суті, це була одна, але дуже сумна скоромовка: «жутко жуку жить на суку». Спочатку ті, хто сиділи в класі, вимовляли її по черзі, потім - хором» (Е. Г. Водолазкин, 2019, с. 28).

Дана вправа давала можливість учням навчитись правильно та чітко розмовляти, покращити вимову, але спосіб викладання наводив на дітей жах «деякі плакали, дивлячись, як, стоячи біля столу, їхня вчителька випускала одну «у» за одною і вони безконтрольно (і моторошно) літали по класу» (Е. Г. Водолазкин, 2019, с. 28).

Справжні педагоги завжди користувались великою пошаною (у прадавні часи їхню роль виконували жерці), вони ставали взірцями для наслідування, виконуючи свою важливу місію передавати набуті знання, виявляти талановитих учнів, сприяти їхньому розвитку. Від таких учителів унаслідувалися не лише знання, але й толерантність, вихованість, тактовність, емоційна стійкість, культура мовлення тощо. Леся Кирилівна не надто намагалась дотримуватись саме такої тактики. Випадок з пародіюванням цією вчителькою учнів класу i, зокрема, дівчинки Плачинди у спустілому після уроків класі (який ця учениця випадково підгледіла) засвідчуе, що поза межами навчального процесу вчителька, відходячи від належних методик, перетворювалася сама на себе, вдаючись навіть до лайливих слів:

«Леся Кирилівна по черзі сідала на місця різних учнів і, наслідуючи їх, тонкими дитячими голосами давала відповіді на вчительські питання. Щоб поставити ці питання, педагог щоразу поверталася за свій стіл і звідти нарочито брутальним голосом зверталася до чергової жертви. Голос їі сам по собі був досить брутальний, так що посилення, строго кажучи, не було потрібне. Найбільше ученицю вразили дві обставини. Перше: відповідаючи в ролі Плачинди, Леся Кирилівна гримасувала, гаряче жестикулювала, і з її писку було зрозуміло, що урок не вивчений. Друге: повернувшись на вчительське місце, Леся Кирилівна обрушила на дівчинку потік добірних матірних лайок. Так, ученищі було неприемно, що хтось бачить її так з боку, так, неприемно, що не вивчено урок, але чому, питається, мат, та ще й який мат!» (Е. Г. Водолазкин, 2019, с. 29).

Лесі Кирилівні бракувало професійної етики й у спілкуванні з батьками дітей. Приміром, на одному з батьківських зборів вона виголошуе: «хлопці ще нічого, а дівчата - дурні» (Е. Г. Водолазкин, 2019, с. 53), об́рунтовуючи даний фокт невмінням учениць зосереджуватись на уроці, а ще правильно писати власні прізвища. Грубість вчительки до дітей майже злочинна - б’e завжди по найболючішому (iї порада, зроблена як зауваження на Глібів сміх, «сховати його конячі зуби» (Е. Г. Водолазкин, 2019, с. 51). Жорстка вимогливість Лесі Кирилівни, зверхність у ставленні до вихованців, байдужість до їхньої особистості створюють їй вкрай негативний імідж вчителятирана (за комунікативною типологію поведінки вчителів, запропонованою американським вченим М. Таленом, а також за моделлю спілкування В. Кан-Каліка та І. Юсупова - вчителька Гліба відповідае типам «генерал» та «монблан» (Моделі спілкування та установка вчителя).

Антиподом Лесі Кирилівни постае викладачка музики - Віра Михайлівна «молода повна дама» (Е. Г. Водолазкин, 2019, с. 29). Найбільше хлопчику імпонувала манера її викладання:

«... його маленька долоня в руках Віри Михайлівни була пластиліном: викладач ліпила з неї руку справжнього домриста. Вона надавала його пальцям правильне положення, іноді стріпувала, як би скидаючи з них всі помилки і неточності, і м'яла, м'яла, м'яла. Саме ця частина занять подобалася Глібу найбільше» (Е. Г. Водолазкин, 2019, с. 29).

Зовнішньому вигляду Віра Михайлівна приділяла не досить уваги. Приміром, на першому уроці гри на гітарі хлопець-оповідувач зауважуе:

«... урок відбувся. I вела його та ж сама Віра Михайлівна - в колишній своїй спідниці, в колишньому жакеті, що почав уже блищати на ліктях. Гліб зрозумів, що чекав оновлення - якщо не Віри Михайлівни в цілому (таке було важко собі уявити), то принаймні 䛠 гардеробу» (Е. Г. Водолазкин, 2019, с. 88).

Передусім вчительку більше цікавила особистість учня, його самопочуття та професійне зростання. Саме Віра Михайлівна подбала про отримання першої особистої домри Гліба, всіляко клопотала про його повернення в музичну школу, коли учень покинув ії. Створивши особливу ауру взаєморозуміння та творчої співпраці, вона сприяла пошукові власної авторської манери хлопця у створенні нюансів, удосконалювала талант юного домриста i, навіть «приводила на його уроки багатьох старших своїх учнів, щоб показати їм, що таке справжне тремоло» (Е. Г. Водолазкин, 2019, с. 93-94). На нашу думку, наведені фрагменти тексту свідчать про правильний педагогічний підхід. Саме таке ставлення до учня сприяе підвищенню його самооцінки, розвиває майстерність, заохочуе до професійного розвитку. У даному разі цінування таланту, одухотворене ставлення до своєї 
професії, ліберальний характер комунікації, створення відповідних умов для самовдосконалення дають змогу стверджувати, що Віра Михайлівна була «педагогом-романтиком» (за класифікацією А. В. Юревича) (Типология предодаватилей высшей школы).

В аспекті значення вчительського іміджу в романі Є. Водолазкіна знаходимо один виразний приклад - це викладачка сольфеджіо Клавдія Василівна (в розмовах учнів - Клавочка), яка викликала у Гліба особливе почуття любові. Хоча сам предмет майже нікому з учнів не подобався, імідж вчительки вдало це компенсував, тому вдома протагоніст «годинами сидів над підручником 3 однією лише метою: не вдарити в бруд обличчям перед Клавочкою» (Е. Г. Водолазкин, 2019, с. 33). Учнів надихали на співпрацю й інші їі особистісні якості: професійна майстерність, культура та манера поведінки:

«... поки Клавочка пояснювала тривалості й особливості нотного стану, нічого поганого навіть не приходило в голову. Перші побоювання стали закрадатися, коли вона перейшла до тризвуччя. Повідомила, що тризвуком називається акорд з трьох звуків, розташованих за терціями. Одна лише радість була в цьому - дивитися на Клавоччині тонкі пальці, якими вона показала тризвуччя на фортепіано: до-мі-соль. Потім заспівала ще: до-мі-соль. Голос ніжний, оксамитовий» (Е. Г. Водолазкин, 2019, с. 31-32).

Олена Марківна, вчителька з музичної літератури, викликала симпатію протагоніста не так своїми особистісними якостями, як предметом викладання. Новаторське мислення, нетипова зовнішність, певна непоміркованість вчинків, нетрадиційний підхід до викладання неабияк імпонували юним музикантам:

«... усупереч шкільним правилам, вимагала, щоб їі називали по імені - Олена, і це було першим пунктом іiі нерозсудливості. Те, що в радянській музичній школі ходила в джинсах, другим. Третім - обходилася без сумки, книги і конспекти пов'язувала сірою кудлатою мотузкою. $<\ldots>$. Обходилася Олена ще без дечого, що по частині нерозсудливості давало, напевно, відразу сотню пунктів, - і вже зовсім в цьому вимірі зашкалювало, коли вона розповідала, що двомісячну вчительську відпустку проводила на Кавказі з хіпі» (Е. Г. Водолазкин, 2019, с. 70-71).

Втім, майстер своєї справи, Олена Марківна повністю віддавала себе роботі: додатково водила дітей на концерти у філармонію, не обмежуючись лише сухою книжковою теорією, чи вивчаючи творчість Е. Гріга і «розповівши про п'есу, вона поставила платівку. Коли звучала Смерть Озі, очі їі були повні сліз. Під час танцю Анітри ледь помітно диригувала - самими кінчиками пальців» (Е. Г. Водолазкин, 2019, с. 71). Однак, відповідно свого запального характеру і великої любові і пошани до метрів класичної музики, Олена Марківна могла різко відреагувати на погану поведінку в класі. Так, почувши, як хлопці сміються з імені Пер Гюнт, вона боляче смикае Гліба за вухо. Проте після уроку компенсуе свій непедагогічний вчинок бесідою: «Не образився? Запитавши, погладила його по підборіддю. <..> Поцілувала його в те вухо, за яке на уроці тягнула: більше не болить?» (Е. Г. Водолазкин, 2019, с. 72). Беручи до уваги типологію викладачів психолога А. В. Юревича, дана модель поведінки Олени Марківни характеризується за типом «викладачпанібрат» (Типология преподавателей в высшей школе, 2013).

Вдалою заміною Олени Марківни став непоказний на перший погляд, однак не менш цікавий і талановитий педагог Павло Петрович Сергеєв:

«... зовні він був таким самим непримітним, як його ім'я, - дядечко років п'ятдесяти в немодних окулярах, які криво сиділи. Голос його був тонкий і деренчливий - таким повідомляють про поломку пружини, - але, коли цим самим голосом Павло Петрович починав розповідати про музику, він перетворювався. Ставав вищий, молодший, охайніший, і окуляри на його носі сиділи вже помітно рівніше» (Е. Г. Водолазкин, 2019, с. 159).

Вміння заінтригувати аудиторію вдало підібраною інформацією, суб'єкт-суб'єктна концепція спілкування, високий інтелектуальний потенціал вчителя плідно позначаються на їхніх вихованцях. Так, розповідаючи про поліфонію в музиці, Павло Петрович суттево скерував майбутні наукові пріорітети протагоніста - в університетські роки Гліб-філолог обрав поліфонію М. Бахтіна за головний концепт своєї наукової роботи.

Особистісне визрівання майбутнього педагога, яким, зокрема, став Гліб, залежить не лише від професійних, індивідуальних особливостей чи рис його зовнішнього вигляду, значну роль відіграють і соціально-історичні події, в яких він перебував за радянських часів свого навчання. Показова у даному ракурсі заувага історика Н. Белової щодо впливу радянських вчителів на навчальний процес, ставати інструментами дороговказу: «Педагоги за радянських часів вважалися не просто носіями знань, які слід було передати підростаючому поколінню, а й провідниками комуністичної ідеології, на них покладалася відповідальність за виховання нового суспільства» (Н. А. Белова, 2015). У романі «Брісбен» автор не оминае і даний концепт. Реакщія вчительки суспільствознавства, яка виявила, що Гліб читав під партою заборонений на той час Закон Божий, була типовою для радянського доби: 
«... може, ми і до церкви ходимо, запитала вона Гліба. <...> Наблизившись до нього впритул, поцікавилася: і молимося, і поклони б'ємо? <...> Б'ємо поклони, перепитала. Не ваша справа, огризнувся Гліб. Ось тут ти, Яновський, помиляешся - моя справа і справа комсомольської організації, якщо, звичайно, ти комсомолець» (Е. Г. Водолазкин, 2019, с. 146).

Авторитарний режим, «чистка» соціуму, обов'язкове дотримання директивних партійних наказів суворо дисциплінували суспільство, провокуючи людей - «гвинтиків системи» на доноси та кон'юнктурне сповідування комуністичної доктрини, формуючи новий культурно-історичний тип нації. Логічно, що вчителька суспільствознавства вважала за свій «обов'язок» донести до відома шкільній адміністрації про крамольну знахідку. Директорка школи, відповідно належної ідеології, відразу ніби відреагувала на прецедент, однак, як зазначаеться у романі,

«обстеживши книгу, директриса подякувала вчительці за пильність, і ця вдячність, як здалося Глібу, була не позбавлена іронії. Про це говорило і «можете йти», недбало кинуте директоркою суспільствознавиці. У Бога літня дама не вірила, але і донощиків не любила. Вона вирішила не ускладнювати Глібу майбутне, обмежившись роз'яснювальною бесідою» (Е. Г. Водолазкин, 2019, c. $147-148)$.

Отже, поспілкувавшись 3 родичами Г. Яновського, директорка виявилася нормальною людиною - вона поступилась комуністичною доктриною, спрацювали її власні моральні критерії, учень не постраждав.

У радянському союзі система навчання передбачала обов'язкове здобуття практичних навичок, тому після закінчення освітнього процесу кожному громадянинові належало віддати державі борг, відпрацювати три роки за спеціальністю. Відповідно Гліб Яновський після університету працюе вчителем російської мови та літератури, однак йому до вподоби стали лише перші місяці роботи:

«Він по-дорослому входив в учительську, брав класний журнал і відправлявся на урок. <...> На нього були спрямовані очі, які не втратили ще дитячої ясності i, мабуть, довірливості. У тому, з якою готовністю <...> діти записували вимовлені ним слова, відчувалася непохитна впевненість у правильності світоустрою, частиною якого був він, Гліб, з його уроками. Від надлишку старанності його учні постійно щось перепитували і уточнювали - йому це подобалося» (Е. Г. Водолазкин, 2019, c. 265-266).

Однак з додатковим навантаженням Глібове ставлення до педагогічної роботи змінилось, адже підготовка до уроків - це складний час, який передбачає не лише підбір необхідної інформації та цікавий метод iї подачі, педагог повинен враховувати вікові особливості аудиторії i, відповідно, розвивати в собі терплячість, гуманність та стриманість, бути психологічно резистентним. Так, приміром, вивчаючи Ф. Достоєвського «Злочин і кара», один з учнів Гліба - Крючков - ставить учителю надто провокаційні питання. На одному з уроків Гліб Федорович, за браком досвіду, порушив професійну етику, зауваживши на весь клас:

«Ти хочеш відстовбурчитися перед дівчатками? <..> Так ось, краще не роби цього за мій рахунок. <..> В кінці уроку зазвичай запитав, чи є питання. Руку знову підняв Крючков. Гліб безпристрасно кивнув. У мене, Гліб Федорович, питання: навіщо мені потрібна російська література? Учитель вийшов з-за столу і повільно попрямував до учня. Клас замовк в очікуванні рукоприкладства. Судячи з усього, на цьому етапі відносин воно вже здавалося всім природним. Підійшовши до Крючкова, Гліб неголосно сказав: тобі російська література не потрібна. Розумовою працею ти, друже, явно займатися не будеш. Станеш кваліфікованим лайночистом, унітази будеш спритно міняти. Голова заповниться зовсім іншим» (Е. Г. Водолазкин, 2019, с. 266-267).

Ситуація вибила вчителя із колії й призвела до втрати авторитету та внутрішньої дисгармонії, натомість, і учень Крючков «смертельно на нього образився і перестав з ним вітатися. Правда, i рота на уроках більше не розкривав» (Е. Г. Водолазкин, 2019, с. 267). Кращий педагогічний хист мала дружина Гліба - Катя. Після закінчення університету вона влаштувалась вчителькою німецької мови в ту ж саму школу, що й чоловік.

«Сама по собі діяльність Каті подобалася. Подобалися діти, <...> якоюсь мірою колеги і навіть прибиральниці, що зустрічали ії загадковим набором звуків - гучних, але доброзичливих. Цим людям приемно було думати, що вони вітаються з вчителькою німецькою мовою. <...>. Про ранковий обмін люб'язностями знала вся школа, і ставлення до Каті ставало від цього тільки кращим. <..>. Крім того, Катя була просто доброю людиною. Це, мабуть, і стало головною причиною того, що колеги не лихословили, прибиральниці віталися, а учні не зривали уроків» (Е. Г. Водолазкин, 2019, с. 274-275).

Психологічно стійкій Каті вдалось примирити Гліба з Крючковим, запросивши учня до себе додому: «З тих пір хлопця як підмінили. Коли на уроках російської літератури він першим піднімав руку, ніхто вже не сміявся. Всі знали, що відповідь Крючкова буде найповнішою, хоча, може бути, і трішки довгою (Е. Г. Водолазкин, 2019, с. 277). Як бачимо, за усіх його талантів Глібові бракувало вміння знаходити компромісні рішення у конфліктах з учнями. 
Вважаємо, що чималу роль у викладацькій діяльності Гліба відіграв досвід стосунків з його власними викладачами. Беручи за приклад правильну, оригінальну та надихаючу модель поведінки вчителя (Віра Михайлівна, Олена Марківна, Іван Олексійович, Беседін, Павло Петрович, Ліза), Гліб намагався наслідувати їхній педагогічний підхід. У такий спосіб, помітивши разючу зміну в поведінці Крючкова 3 вищенаведеного епізоду, протагоніст змінився й сам: налагодив відносини з учнями й колегами, сумлінніше ставився до матеріалу, враховуючи вподобання учнів, більш професійно і нестандартно підходив до уроків. Приміром, на одні з вихідних він поїхав з класом на могилу Анни Ахматової в Комарово, де діти по черзі читали їі вірші (Е. Г. Водолазкин, 2019, с. 277). Попри змогу краще засвоїти матеріал, вивчити біографію й тонкощі творчості знаної акмеїстки, це активізувало учнівський потенціал.

Цікаво, що у романі «Брісбен» відтворено не лише досвід шкільної освіти радянських часів, але й вишівський. Університетська методика викладання, на відміну від шкільної, у будь-якому разі передбачае інакший формат підготовки фахівців. У той час, як шкільні викладачі прикликані допомагати у формуванні моральних і професійних якостей підліткової молоді, вузівська педагогіка спрямована на потреби професії, удосконалення, поглиблення відповідних знань, ставати дороговказом у світ майбутніх професій. Звідси для студентства головно, щоб викладач вишу передусім відповідав фаховим вимогам. Зрозуміло, що Глібові в університеті було важливо знайти хорошого керівника, «який, на його думку, відповідав би завданням задуманого дослідження» (Е. Г. Водолазкин, 2019, с. 208). Отже, лише аспірант Іван Олексійович Сергіенко, маючи «літературне прізвище й ім'я» (Е. Г. Водолазкин, 2019, с. 208), а також неабияку ерудицію, здавався відповідним до зацікавлень юного науковця. Проте, не лише зовнішній вигляд, манера поведінки, вміння спілкуватись з молоддю на рівних приваблювали протагоніста. В обох було спільне захоплення, яке ще більше налаштовувало на співпрацю: «Іван Олексійович грав на гітарі. Не те щоб був віртуозом, але грав з почуттям і був душею компанії. Грав і співав - Окуджаву, Висоцького, Кіма. У перевірених компаніях - Галича» (Е. Г. Водолазкин, 2019, с. 208). У тексті неодноразово підкреслюеться й нонконформістська система викладання молодого наставника:

«Глібу подобалося ще й те, що, на відміну від керівників-професорів, Іван Олексійович не дошкуляв його строгим контролем. Зустрічалися вони досить рідко - i не на кафедрі, а в пивній Бригантина. Наставник задовольнявся усними повідомленнями підопічного. Слухав уважно, іноді перебивав, перепитував. І завжди давав гарні поради. <...> 3 одного бару переміщалися в інший, i у Івана Олексійовича не убожіла дотепність, а головне - гаманець, тому що за все платив тільки він. Гліб кілька разів намагався увійти в долю, але Іван Олексійович нагадав йому, що в даному випадку має місце навчальний процес, за який він, як керівник, несе повну (в тому числі фінансову) відповідальність. Це був найрадісніший, але разом з тим і плідний навчальний процес в житті Гліба» (Е. Г. Водолазкин, 2019, с. 209, 210, 211).

Втім бунтарський характер аспіранта Сергієнка, богемність, самобутній підхід у навчанні студентів і відверто критичне ставлення до радянської влади зрештою призвели до його звільнення "через порушення викладацької етики» (Е. Г. Водолазкин, 2019, с. 225). Натомість Глібовим науковим керівником став 80-річний професор Беседін - інший тип вишівського викладача, цілковита протилежність Івана Олексійовича, відтворений за аналогією з якимось могутнім дубом:

«З кожним прожитим роком минуле все більше уявлялося йому чимось недостовірним і таким, що безпосередньо до нього не відноситься. Єдиною його супутницею була різьблена палиця: вони здавалися створеними одне для одного. Горбисті пальці обмотували їі рукоять на манер коренів, роблячи очевидним разючу схожість професора і його тростини - в малюнку, кольорі і матеріалі» (Е. Г. Водолазкин, 2019, с. 208).

Професійність i досвідченість викладача виказувалися його віком i психологічною врівноваженістю у роботі зі студентами, проте акцентуеться й певне професійне виснаження професора:

«Він вважав за краще, щоб Гліб писав роботу, засновану на текстологічних методах, і навіть запропонував йому кілька тем. Гліб, проте, зумів наполягти на своєму. Власне, і наполягати було не потрібно: не бажаючи хвилюватися, Беседін давно вже не вступав в суперечки. Поліфонія так поліфонія, сказав він ласкаво» (Е. Г. Водолазкин, 2019, с. 235).

Однак, як особистість, Беседін не втратив висоти: полеміка з доцентом Чукіним на дипломному захисті, допомога із пропискою та пошуком житла для Гліба - такі епізоди свідчать про високі моральні якості керівника, емпатію, любов до науки, об’єктивність, а головно - вміння захистити позицію свого учня.

Стосунки між колегами у науковому середовищі висвітлено у романі саме в аспекті етики. Відомо, що ще, починаючи з часів античності, між педагогами повсякчас точилася запекла конкуренція, позаяк від кількості учнів залежало не лише благополуччя вчителя, але слава й 
авторитет його поглядів (Т. Б. Перфилова, 2004). Автор «Брісбену» також не оминає увагою відповідну проблему: так, доцент Чукін, який побудував наукову кар'еру на суперечці 3 М. Бахтіним, перед студентами намагаеться іронізувати 3 тих дослідників (серед них був I. О. Сергієнко), які відстоювали ідею поліфонії в літературі. У такий спосіб викладач намагався створити собі «тіньовий імідж», вважаючи, що подібне заохотить учнів підтримувати його погляди i забезпечить подальшу співпрацю з ними.

У романі ми зустрічаемо ще один значущий акцент - спадковість в обранні викладацької діяльності. Так, в аспекті нашої теми, вважаемо цікавим персонажем з-посеред родичів Гліба двоюрідну сестру Лізу - ленінградську викладачку-філологиню, яка постає в його очах зразковим педагогом, людиною високопрофесійною, широкого кругозору, бездоганної етики. Так, надзвичайно цікавим постае їі наратив, що передае оригінальність методичниого підходу до теми заняття (лекція із заочниками), «присвяченого розвиткові значення слів» (Е. Г. Водолазкин, 2019, с. 172). Ототожнюючи «слово» 3 «людиною», Ліза фактично відштовхуеться від перших слів Свангелія від Іоанна «Споконвіку було Слово, а Слово в Бога було, і Бог було Слово ...» (Біблія або Книги святого письма Старого й Нового заповіту, с. 112): «Слово, вчила заочників Ліза, як людина: має свою історію і не завжди було таким, яким ми його знаємо зараз» (Е. Г. Водолазкин, 2019, с. 172).

Показово, що нею за приклад не випадково береться слово «успіх» (його можна вважати ключовим словом всього роману, у якому йдеться про непросте життя видатного музиканта Гліба на шляху до успіху). Тлумачення Лізою цього слова містить особливе фрункціональне навантаження, фокусуючи нашу увагу на узагальненій темі романного тексту:

«... слово успіх в давнину мало три основних значення. Першим і найважливішим було значення користь (Ліза написала слово на дошці), перш за все користь духовна. <...> Другим значенням був рух вперед, просування - наприклад, по службі. Нарешті, трете значення слова успіх передається сучасним (i родинним успіху) словом поспішність» (Е. Г. Водолазкин, 2019, c. 172).

Викладачка у цій «лекції для заочників» підкреслюе, що час завжди вносить певні корективи в семантичне наповнення слова i що воно у звуженому сенсі здатне перетворитися на нову парадигму - «використовуючи однокореневе слово, можна сформулювати це так, що успіх супроводжуе того, хто встиг» (Е. Г. Водолазкин, 2019, с. 173). Підкреслюеться - «яка вже тут духовна користь?» (Е. Г. Водолазкин, 2019, с. 173), коли розглядаються сучасні значення ціеї парадигми:

«Так, вираз встати з успіхом означало не вдале, а поспішне вставання. Словники сучасної мови в слові успіх виділяють переважно два значення. Перше визначається як позитивний результат, вдале завершення; друге - як суспільне визнання. Ні те, ні інше значення не пов'язане з користю. <...> Два інших давньоруських значення стоять ближче до сучасних значень слова» (Е. Г. Водолазкин, 2019, с. 173).

У такий спосіб цікава своїм інформативним дискурсом пара Лізи у створеній нею атмосфері сприятливості, де був присутній Гліб, викликала у хлопця величезну гордість за сестру, більше того, вплинула на його рішення здобути вищу філологічну освіту в Ленінграді, хоча, насправді, це було відхиленням від шляху успіху його як музиканта зі світовим ім'ям.

Обговорення/Discussion. Окрім того, що в усі часи діяльність педагога мала велике значення - передавати знання, надихати і бути хорошим наставником, ділитись досвідом, розвивати нові вміння та навички учнів, вміти розгледіти їхній потенціал та допомогти його розвинути, значущим також вважаеться обов'язок працювати над своїм іміджем, відповідати професійним запитам на усіх рівнях. Питанню іміджології та вимог до образу викладача на сьогодні присвячено у світовій науці чимало досліджень з педагогіки (П. Бреда, Л. Брауна, $\begin{array}{llll}\text { Д. Ягера, О.В.Ярошевич, } & \text { Ф. О. Кузіна, Л. М. Мітіна, } & \text { С. М. Захарова, } & \text { В. М. Шепель, }\end{array}$ А. А. Калюжний, О. Ю. Панасюк, О. О. Петрова, Л. П. Іноземцева, О. І. Попова та ін.).

У загальних рисах висновок такий: хороший вчитель, майстер своєї справи повинен володіти такими рисами, як доброзичливість, розвинена емпатія, справедливість, урівноваженість, відповідальність, тактовність, почуття гумору, життерадісність, терплячість, пунктуальність, гуманність, соціальна активність, порядність, гідність, вихованість, дотримання субординації, самовдосконалення, креативність, уміння спілкуватись; вміти цікаво подати учбовий матеріал, мати належну професійну підготовку i вигляд, бути вмілим організатором i виконавцем навчального процесу, експертом у відповідній до свого фаху галузі знань, здатним до самовдосконалення, розвитку творчого потенщіалу; мати сміливість, готовність до ризику, ентузіазм, наполегливість, допитливість, психологічну гнучкість й, водночас, стійкість переконань, бути вимогливою, витриманою особистістю (В. Ярошевич, 2015; С. Захарова, 2015; С. Тимків, 2014; Г. М'ясоїд, 2015; Г. Загоруй ; Л. Колесникова, 2011; Н. Мирончук, 2015; В. Кувачов, Т. Чорна, В. Мітков, 2019; О. Внукова, 2016). 
Досить велика увага у розвідках вчених надається зовнішньому вигляді викладача, його манері поведінки (досліджуються міміка, жести, одяг, тембр голосу тощо), позаяк це перше, що сприймають учні (В. Ярошевич, 2015; С. Захарова, 2015; С. Тимків, 2014; А. Пучков, 2012; Л. Иноземцева， 2011; Е. Ларина， 2013; В. Кувачов， Т. Чорна， В. Мітков， 2019). Соціологічні опитування дають змогу констатувати, що учні / студенти створюють власні критерії до образу педагогів, серед яких найбільше цінуються зовнішність, професійні (досконале знання свого предмету, володіння ораторським мистецтвом, постійність у судження, вимогливість, інтелігентність, творчий і психологічний підходи, доступність викладу матеріалу) й особистісні (доброзичливість, справедливість, комунікабельність, толерантність, стриманість, увічливість, вихованість, дисциплінованість, бажання працювати та викладати, об’ективність, готовність допомагати, оптимізм, людяність, інтелігентність, терплячість, цілеспрямованість, самокритичність, демократичність, відповідальність) якості (А. Пучков, 2012; Л. Иноземцева, 2011; Е. Ларина, 2013; О. Попова, 2011; Л. Позина, 2011; В. Кувачов, Т. Чорна, В. Мітков, 2019). В романі Водолазкіна «Брісбен» усі ці покажчики промальовуються дуже виразно, реципіент має можливість простежити відповідний процес створення комунікації між вчителем і учнем через імідж педагога.

Висновки/Conclusions. Таким чином, розглянувши роман Є. Водолазкіна «Брісбен» передусім з позицій педагогічної науки (хоча автор, звичайно, не на це розраховував!), ми маємо надзвичайно промовистий літературний приклад того, що вузівська та шкільна методики викладання мають чималі розбіжності, проте особистість вчителя як така постае сталим спільним концептом, позаяк відіграє найпершу роль у формуванні особистості. Навіть імідж педагога може впливати не лише на успішність учнів, а й на базове формування їхньої індивідуальності, на їхній майбутній шлях.

Виконуючи транзитивну функцію провідника між минулим і сучасним, педагог водночас виступае заручником соціально-політичних подій свого часу, як це яскраво демонструе і текст Водолазкіна стосовно педагогіки радянських часів. У наш час цінуються дещо інші педагогічні якості, ніж епохою раніше: гнучкість та мобільність методики, скоріше фахова, ніж інтуїтивна опора на здобутки психологічної науки, володіння інформаційними технологіями, вміння бути хорошим модератором тощо. У цілому, гарантами педагогічної успішності, виходячи з розглянутого тексту, постають такі незмінні маркери, як високий рівень професійних якостей, увага до вихованців, позиція наставника у соціумі з усвідомленим ставленням до відповідних вимог часу.

"Брисбенн" Водолазкин Евгений Герланович - описание книги (б.д.). Retrieved from: https://ast.ru/book/brisben-839240/. [in Russian]

Водолазкин, Е. Г. (2019). Брисбен: ролан. Москва. [in Russian]

Евгений Водолазкин (б.д.). Retrieved from: https://24smi.org/celebrity/59135-evgenii-vodolazkin.html. [in Russian]

Интервью: Евгений Водолазкин: “Человек - как печка: долго топится, потол греет других». (2019). Retrieved from: https://teletype.in/@vodolazkin/evgenij-vodolazkin-chelovek-kak-pechka-dolgo-topitsya-potomgreet-drugix. [in Russian]

Биографбия. Евгений Водолазкин (б.д.). Retrieved from: https://evgenyvodolazkin.ru/biografiya/. [in Russian]

Интервью: Лицом к лицу. Евгений Водолазкин: «Каждый роман - это вновь создаваемый мир». (2019). Юность, 8 (763), 120-124. [in Russian]

Рыбаков, С. Ю. (2014). Духовные процессы и тенденции в системе советского образования в период 30 90-х гг. XX столетия. Теория и практика общественного развития, 13, 79-84. [in Russian]

Шевченко, С. М. (2013). Стан розвитку російських шкіл в УРСР (кінець 30-х - 40-ві pp. ХХ ст.). Психолого-педагогічні науки, 5, 126-131.

Ярошевич, О. В. (2015). Имидж преподавателя как составляющая качества системы геометрографической подготовки студентов. Инновационные технологии в инженерной грабике: проблель и перспективы: сборник трудов междунар. науч.-практ. конф. (с. 140-149). Новосибирск. [in Russian]

Захарова, С. М. (2016). Имидж педагога как составляющая профессиональной компетентности. Молодой ученый, 5.1, 16-18. [in Russian]

Тимків, I. С. (2014). Вимоги до особи викладача в сучасному освітньому просторі. Архів клінічної медииини, 1, 109-111. [in Ukrainian]

Пучков, А. А. (2012). Идеальный образ преподавателя: социологический опрос. Высшее образование в России, 6, 130-133. [in Russian]

Иноземцева, Л. П. (2011). Имидж преподавателя как составляющая его профессиональной личности. Вестник Челябинско го государственного университета, 24, 231-232. [in Russian]

Ларина, Е. Н. (2013). Изучение представлений студентов о профессионально важных качеств как «идеального» и «реального» преподавателя. Концеnт, 11 (ноябрь), 86-90. [in Russian]

Попова, О. И. (2011). Имидж преподавателя вуза: проблема самореализации в образовательном взаимодействии. Педагогическое образование в России, 4, 224-232. [in Russian]

М'ясоїд, Г. І. (2015). Сучасні вимоги до викладача вищої школи: огляд тенденцій світової педагогічної 
практики. Педагогічні науки: теорія, історія, інноваційні технологї, 3, 107-113. [in Ukrainian]

from:

Загоруй, Г. В. (2010). Профресіограма викладача вищої школи та шляхи їі реалізації (редерат). Retrieved

https://www.psyh.kiev.ua/\%D0\%9F\%D1\%80\%D0\%BE\%D1\%84\%D0\%B5\%D1\%81\%D1\%96\%D0\%BE\%D0\%B3\%D1\% 80\%D0\%B0\%D0\%BC\%D0\%B0\%D0\%B2\%D0\%B8\%D0\%BA\%D0\%BB\%D0\%B0\%D0\%B4\%D0\%B0\%D1\%87\%D0\%B0 _\%D0\%B2\%D0\%B8\%D1\%89\%D0\%BE\%D1\%97_\%D1\%88\%D0\%BA\%D0\%BE\%D0\%BB\%D0\%B8_\%D1\%82\%D0\%B0_ \%D1\%88\%D0\%BB\%D1\%8F\%D1\%85\%D0\%B8_\%D1\%97\%D1\%97_\%D1\%80\%D0\%B5\%D0\%B0\%D0\%BB\%D1\%96\%D 0\%B7\%D0\%B0\%D1\%86\%D1\%96\%D1\%97_\%D1\%80\%D0\%B5\%D1\%84\%D0\%B5\%D1\%80\%D0\%B0\%D1\%82 \%D0\%9 7\%D0\%B0\%D0\%B3\%D0\%BE\%D1\%80\%D1\%83\%D0\%B9_\%D0\%93.\%D0\%92.). [in Ukrainian]

Колесникова, Л.Н.(2011). Профессиональный имидж преподавателя. Ученые записки, 209-215. [in Russian]

Позина, Л. Т. (2011). Современный образ преподавателя высшей школы. Записки горного института, 193, 139-142. [in Russian]

Мирончук, Н. М. (2015). Кваліфікаційні вимоги до викладачів вищих навчальних закладів як основа змісту освітньо-професійних програм підготовки фахівців. Проблели освіти, 82, 172-176. [in Ukrainian]

Белова, Н. А. (2015). Повседневная жизнь учителей. Москва. [in Russian]

Типология преподавателей в вьсшей школе. (2013). Retrieved from: http://fevt.ru/load/pedagogika/tipologii_prepodavatelei/119-1-0-1491. [in Russian]

Моделі спілкування та установка вчителя (б.д.). Retrieved from:

http://studentam.net.ua/content/view/3435/97/. [in Ukrainian]

Перфилова, Т. Б. (2004). «Странствующие» софисты в культурном пространстве провинции (на примере биографии Либания. Известия Российского гос. педагогического университета им. А. И. Гериена. Общественные и гуманитарные науки, 4, 7-15. [in Russian]

Кувачов, В. П., Чорна, Т. С., \& Мітков, В. Б. (2019). Імідж викладача, як фактор мотивації студентів. Удосконалення освітньо-виховного процесу в закладі вищої освіти, 22, 216-225. [in Ukrainian]

Федірчик, Т. (2009). Саморозвиток викладача як складова науково-методичної системи розвитку його педагогічного професіоналізму. Науковий вісник Чернівецького університету, 729, 137-144. [in Ukrainian]

Внукова, О. М. (2016). Позитивний імідж викладача як показник його педагогічної майстерності. Гуманітарний вісник ДВНЗ «Переяслав-Хмельницький державний педагогічний університет ілені Григорія Сковороди», 36, 15-21. [in Ukrainian]

Біблія або Книги святого письма Старого й Нового заповіту. (1991). Свята Євангелія від Івана. Українське біблійне товариство. [in Ukrainian]

https://ast.ru/book/brisben-839240/. [in Russian]

Vodolazkin, E. G. (2019). Brisben: roman. Moskva. [in Russian]

Yevgenij Vodolazkin (b.d.). Retrieved from: https://24smi.org/celebrity/59135-evgenii-vodolazkin.html. [in Russian]

Intervyu: Yevgenij Vodolazkin: "Chelovek - kak pechka: dolgo topica, potom greet drugix». (2019). Retrieved from: https://teletype.in/@vodolazkin/evgenij-vodolazkin-chelovek-kak-pechka-dolgo-topitsya-potom-greet-drugix. [in Russian]

Biografiya. Yevgenij Vodolazkin (b.d.). Retrieved from: https://evgenyvodolazkin.ru/biografiya/. [in Russian]

Intervyu: Licom k licu. Yevgenij Vodolazkin: «Kazhdy’j roman - e’to vnov' sozdavae'my’j mir». (2019). Yunos't, 8 (763), 120-124. [in Russian]

Ry'bakov, S. Yu. (2014). Duxovny'e processy' i tendencii v sisteme sovetskogo obrazovaniya v period 30-90-x gg. XX stoletiya. Teoriya i praktika obshchestvennogo razvitiya, 13, 79-84. [in Russian]

Shevchenko, S. M. (2013). Stan rozvytku rosiiskykh shkil v URSR (kinets 30-kh - 40-vi rr. XX st.). Psykholoho-pedahohichni nauky, 5, 126-131.

Yaroshevych, O. V. (2015). Imidzh prepodavatelya kak sostavlyayushchaya kachestva sistemy' geometrograficheskoj podgotovki studentov. Innovacionny'e texnologii v inzhenernoj grafike: problemy' $i$ perspektivy': sbornik trudov mezhdunar. nauch.-prakt. konf. (s. 140-149). Novosibirsk. [in Russian]

Zaxarova, S. M. (2016). Imidzh pedagoga kak sostavlyayushchaya professional'noj kompetentnosti. Molodoj ucheny’, 5.1, 16-18. [in Russian]

Tymkiv, I. S. (2014). Vymohy do osoby vykladacha v suchasnomu osvitnomu prostori. Arkhiv klinichnoi medytsyny, 1, 109-111. [in Ukrainian]

Puchkov, A. A. (2012). Ideal'ny'j obraz prepodavatelya: sociologicheskij opros. Vy'sshee obrazovanie v Rossii, 6, 130-133. [in Russian]

Inozemceva, L. P. (2011). Imidzh prepodavatelya kak sostavlyayushchaya ego professional'noj lichnosti. Vestnik Chelyabinskogo gosudarstvennogo universiteta, 24, 231-232. [in Russian]

Larina, E. N. (2013). Izuchenie predstavlenij studentov o professionalno vazhny'x kachestv kak «idealnogo» i «real'nogo» prepodavatelya. Koncept, 11 (noyabr), 86-90. [in Russian]

Popova, O. Y. (2011). Imidzh prepodavatelya vuza: problema samorealizacii v obrazovatel'nom vzaimodejstvii. Pedagogicheskoe obrazovanie v Rossii, 4, 224-232. [in Russian]

Miasoid, H. I. (2015). Suchasni vymohy do vykladacha vyshchoi shkoly: ohliad tendentsii svitovoi pedahohichnoi praktyky. Pedahohichni nauky: teoriia, istoriia, innovatsiini tekhnolohii, 3, 107-113. [in Ukrainian]

Zahorui, H. V. (2010). Profesiohrama vykladacha vyshchoi shkoly ta shliakhy yii realizatsii (referat). 
Retrieved

from:

https://www.psyh.kiev.ua/\%D0\%9F\%D1\%80\%D0\%BE\%D1\%84\%D0\%B5\%D1\%81\%D1\%96\%D0\%BE\%D0\%B3\%D1\% 80\%D0\%B0\%D0\%BC\%D0\%B0_\%D0\%B2\%D0\%B8\%D0\%BA\%D0\%BB\%D0\%B0\%D0\%B4\%D0\%B0\%D1\%87\%D0\%B0 _\%D0\%B2\%D0\%B8\%D1\%89\%D0\%BE\%D1\%97_\%D1\%88\%D0\%BA\%D0\%BE\%D0\%BB\%D0\%B8_\%D1\%82\%D0\%B0_ \%D1\%88\%D0\%BB\%D1\%8F\%D1\%85\%D0\%B8_\%D1\%97\%D1\%97_\%D1\%80\%D0\%B5\%D0\%B0\%D0\%BB\%D1\%96\%D 0\%B7\%D0\%B0\%D1\%86\%D1\%96\%D1\%97_(\%D1\%80\%D0\%B5\%D1\%84\%D0\%B5\%D1\%80\%D0\%B0\%D1\%82_\%D0\%9 7\%D0\%B0\%D0\%B3\%D0\%BE\%D1\%80\%D1\%83\%D0\%B9_\%D0\%93.\%D0\%92.). [in Ukrainian]

Kolesnikova, L. N. (2011). Professionalny’j imidzh prepodavatelia. Ucheny'e zapiski, 209-215. [in Russian]

Pozina, L. T. (2011). Sovremenny’j obraz prepodavatelya vy'sshej shkoly'. Zapiski gornogo instituta, 193, 139142. [in Russian]

Myronchuk, N. M. (2015). Kvalifikatsiini vymohy do vykladachiv vyshchykh navchalnykh zakladiv yak osnova zmistu osvitno-profesiinykh prohram pidhotovky fakhivtsiv. Problemy osvity, 82, 172-176. [in Ukrainian]

Belova, N. A. (2015). Povsednevnaya zhyzn' uchitelej. Moskva. [in Russian]

Tipologiya prepodavatelej $v$ vy'sshej shkole. (2013). Retrieved from: http://fevt.ru/load/pedagogika/tipologii_prepodavatelei/119-1-0-1491. [in Russian]

Modeli spilkuvannia ta ustanovka vchytelia (b.d.). Retrieved from: http://studentam.net.ua/content/view/3435/97/. [in Ukrainian]

Perfilova, T. B. (2004). "Stranstvuyushchie» sofisty' v kul'turnom prostranstve provintcii (na primere biografii Libaniy. Izvestiya Rossiskogo gos. pedagogicheskogo universiteta im. A. I. Gercena. Obshchestvenny'e $i$ gumanitarny'e nauki, 4, 7-15. [in Russian]

Kuvachov, V. P., Chorna, T. S., \& Mitkov, V. B. (2019). Imidzh vykladacha, yak faktor motyvatsii studentiv. Udoskonalennia osvitno-vykhovnoho protsesu v zakladi vyshchoi osvity, 22, 216-225. [in Ukrainian]

Fedirchyk, T. (2009). Samorozvytok vykladacha yak skladova naukovo-metodychnoi systemy rozvytku yoho pedahohichnoho profesionalizmu. Naukovyi visnyk Chernivetskoho universytetu, 729, 137-144. [in Ukrainian]

Vnukova, O. M. (2016). Pozytyvnyi imidzh vykladacha yak pokaznyk yoho pedahohichnoi maisternosti. Humanitarnyi visnyk DVNZ "Pereiaslav-Khmelnytskyi derzhavnyi pedahohichnyi universytet imeni Hryhoriia Skovorody", 36, 15-21. [in Ukrainian]

Bibliia abo Knyhy sviatoho pysma Staroho y Novoho zapovitu. (1991). Sviata Yevanheliia vid Ivana. Ukrainske bibliine tovarystvo. [in Ukrainian]

Дата надходження статті: «06» травня 2021 р.

Стаття прийнята до друку: «17» червня 2021 р.

Калинич Катерина - аспірантка Чернівецького національного університету імені Юрія Федьковича Kalynych Kateryna - postgraduate student of Yuri Fedkovich Chernivtsi National University

Цитуйте ию статтюяк:
Калинич, К. $\quad$ (2021). Художній текст як

